Bull. Fac. Agric. Cairo Univ. 60: 213-218 (2009)

\title{
OLIVE OIL ELEMENTAL CONTENT OF TWO LOCAL GENOTYPES AS INFLUENCED BY RECYCLED EFFLUENT IRRIGATION UNDER ARID ENVIRONMENT
}

(Received: 26.10.2008)

\author{
By \\ K. M. Al-Absi and O. E. Mohawesh* \\ Plant Production Department, Faculty of Agriculture, Mu'tah University, \\ Al-Karak 61170, Jordan.* Corresponding author.
}

\begin{abstract}
Effect of recycled effluent irrigation was investigated on quality, elemental composition $(\mathrm{Ca}$, $\mathrm{Cd}, \mathrm{Co}, \mathrm{Fe}, \mathrm{K}, \mathrm{Mn}, \mathrm{Mg}, \mathrm{Na}, \mathrm{Pb} \mathrm{Cl}$ and $\mathrm{Zn}$ ) and of two local olive genotypes (Olea europaea $\mathrm{L}$.) under field conditions during two complete vegetative cycles. The analysis of the effluent indicated that element concentrations fall within the permissible range for irrigation except $\mathrm{Na}$ and $\mathrm{Mg}$. The $\mathrm{Ca}, \mathrm{Cl}, \mathrm{K}, \mathrm{Mn}, \mathrm{Na}$ and $\mathrm{Zn}$ were found in all oils of trees irrigated with wastewater and fresh water. However, the concentration of these elements was higher in the olive oil of trees irrigated with treated wastewater than olive oil of trees irrigated with fresh water but lower than the maximum permissible concentration. The concentrations ranged from 8.90 to $26.15 \mathrm{mg} \mathrm{kg}^{-1}$ for $\mathrm{Ca} ; 0.07$ to $0.13 \%$ for $\mathrm{Cl} ; 53.19$ to $111.75 \mathrm{mg} \mathrm{kg}^{-1}$ for $\mathrm{K}, 0.97$ to $1.46 \mathrm{mg} \mathrm{kg}^{-1}$ for $\mathrm{Mn} ; 6.24$ to $16.10 \mathrm{mg} \mathrm{kg}^{-1}$ for $\mathrm{Na}$ and 0.19 to $0.36 \mathrm{mg} \mathrm{kg}^{-1}$ for $\mathrm{Zn}$. The effect of irrigation water quality on oil quality indices (peroxide and acidity) was not significant. There were significant correlations between the concentrations of the pairs $\mathrm{Ca}-\mathrm{Na}, \mathrm{Zn}$. These results indicate that this kind of effluent is suitable for irrigation of olive genotypes grown for oil purposes.
\end{abstract}

Key word: irrigation, minerals, oil quality, olive, recycled water.

\section{INTRODUCTION}

Water scarcity in the Mediterranean countries, especially in countries in the arid zone with high rates of population growth, urbanization and industrialization, appears as one of the main factors limiting agricultural development. Jordan is considered to be one of the ten poorest countries worldwide in water resources. Due to the limited water resources and the relatively high population growth rate $(2.5 \%, 2004)$, the annual per capita share is expected to decrease from 160 $\mathrm{m}^{3}$ in recent years to less than $90 \mathrm{~m}^{3}$ by 2025 (Shatanawi et al., 2003). The irrigation share of the total water uses demonstrates significant decrease during the period 19852008 (78\% in 1975 to $60 \%$ in the year 2008). Within the next 25 years, although irrigated areas will increase, large quantities of fresh water supplies will be diverted from agriculture to meet the growing water demand in the municipal and industrial sectors in the region (Hamdi et al., 1995; Correia, 1999). In order to overcome water shortages and to satisfy the increasing water demand for agricultural development, the use of water of low quality (brackish, reclaimed, drainage) is becoming important in many countries like Jordan.

An alternative plan for saving water could include the use of non-conventional water resources such as the treated wastewater. The main health risks are associated with contamination of crops by wastewater due to its chemical composition being somewhat different from most natural waters used in irrigation (Pereira et al., 2002). Ion toxicity and nutritional disturbances are detrimental effects of wastewater on plant growth and yield quality (Cheesman, 1988). Siebe (1995) found that wastewater irrigation increased heavy metals contents of soils with time, and plant uptake of $\mathrm{Cd}$ and $\mathrm{Pb}$ also increased.

Olive (Olea europaea L.) has been grown commercially in Jordan for many years. In the last three decades, olive plantation extended almost to all regions of the country, particularly the eastern and northern parts. 
Currently, olive plantations encompass about 103,840 ha with annual production of around 148.2 thousand tons (Ministry of Agriculture, 2005).The objective of this work was to study the effects of the reuse of recycled effluent (from Al-Hussein Bin Abdullah II Industrial Estate Wastewater Treatment Plant) as textile factories wastes mixed with municipal domestic effluent on olive oil quality of two local olive cultivars (about $70 \%$ of the cultivars currently grown in Jordan) at field conditions.

\section{MATERIALS AND METHODS}

2.1. Experimental sites and water source

This study was carried out at the olive orchard of Al-Hussein Bin Abdullah II Industrial Estate (HUIE) which is located about $20 \mathrm{~km}$ east of Karak city during the period March, 2004 - January, 2006. The area is characterized with cool winter and very hot summers. The total rainfall in average years is below $150 \mathrm{~mm} /$ year. The treated wastewater used in this study was taken from the HUIE Wastewater Treatment Plant. This water is mainly generated by textile firms mixed with municipal domestic effluent. The treatment current flow is about $500 \mathrm{~m}^{3} \mathrm{~d}^{-1}$. Chemical characteristics of the effluent were determined during the growing season as presented in (Table 1).

\subsection{Orchard site and irrigation treatments}

Five years old trees of the two cultivars ('Nabali' and 'Improved Nabali') were used at the field experiment. These genotypes were selected for their widespread planting in orchards and nurseries, both private and public. The olive trees in the field experiment were trickle irrigated with fresh water (av. EC $0.82 \mathrm{dS} \mathrm{m}^{-1}$ ) and treated wastewater (av. EC $4.20 \mathrm{dS} \mathrm{m}^{-1}$ ). Both treatments were given the same amount of irrigation quantity. In order to define water volumes, $\mathrm{ET}_{\mathrm{c}}$ (crop evapotranspiration) was calculated multiplying $\mathrm{ET}_{\mathrm{o}}$ by crop coefficient $\left(\mathrm{K}_{\mathrm{c}}\right.$ ranged from 0.65 to 0.70 ). The total irrigation quantity applied each season was about 800 $\mathrm{mm}$. The fruits were harvested from olives trees from both treatments and oil was extracted. Oil elemental composition and quality were analyzed.

\subsection{Oil microwave-assisted acid decomposition}

Oil samples were stored in dark glass bottles at $4^{\circ} \mathrm{C}$ until the time of analysis. To dissolve the oil samples for elemental analysis, microwave-assisted acid decomposition was performed at high pressure and temperature. The digestion was carried out as follows: $6 \mathrm{ml}$ of nitric acid at $69.5 \%$, and $1 \mathrm{ml}$ of hydrogen peroxide $30 \%$ were added to $1 \mathrm{~g}$ of oil. A CEM model MarsX Microwave-assisted system was used. The microwave operation parameters were: power $250 \mathrm{~W}$ for $1 \mathrm{~min}, 0 \mathrm{~W}$ for $1 \mathrm{~min}, 250$ $\mathrm{W}$ for $5 \mathrm{~min}, 400 \mathrm{~W}$ for $5 \mathrm{~min}, 650 \mathrm{w}$ for 5 min; maximum temperature was $200{ }^{\circ} \mathrm{C}$. After digestion, samples were allowed to cool to room temperature for $12 \mathrm{hr}$; the residues were taken up to $25 \mathrm{ml}$ with bi-distilled water.

\subsection{Oil elemental composition determination}

The $\mathrm{Ca}, \mathrm{Cd}, \mathrm{Co}, \mathrm{Cu}, \mathrm{Fe}, \mathrm{K}, \mathrm{Mn}, \mathrm{Mg}, \mathrm{Na}$, $\mathrm{Ni}, \mathrm{P}, \mathrm{Pb}$ and $\mathrm{Zn}$ concentrations were determined by atomic emission spectrometer (Jobin Yvon Emission - JY 38 S, Paris, France) (Tandon, 1995). Detection limits for the elements were below $0.1 \mathrm{mg} \mathrm{kg}^{-1}$. The calibration was performed by using five aqueous standard solutions in $5 \% \mathrm{HNO}_{3}(\mathrm{v} / \mathrm{v})$. The calibration standard solutions have the following concentrations: $0,0.2,0.5,2.0$, and $5.0 \mathrm{mg} / \mathrm{L}$. The acidity of the standard and sample solutions was the same $\left(5 \% \mathrm{HNO}_{3}\right)$. Chloride was titrated by $\mathrm{AgNO}_{3}$.

\subsection{Statistical design and analysis}

Randomized complete block design (RCBD) consisted of two cultivars, two irrigation water qualities and four replicates were used at HUIE field experiment. Each replicate was represented by three trees. Statistical assessments of differences between mean values were performed by LSD test at $\mathrm{P}=0.05$ according to Snedecor and Cochran (1980) using MSTATC statistical package (Michigan State Univ., East Lansing, MI).

\section{RESULTS AND DISCUSSION 3.1. Irrigation water quality}

The chemical analysis of the treated wastewater and fresh water used for irrigation was determined by the methods described by Greenberg et al. (1985) (Table 1). In general, levels of most metals were below the recommended maximum concentrations and within guidelines for irrigation of agricultural crops (Ayers and Westcot, 1985). It is clear that the wastewater had higher concentrations of sodium ( $\mathrm{Na}$ ) and magnesium ( $\mathrm{Mg}$ ) than 
Table (1): Chemical characteristic of the treated waste water and potable used for irrigation.

\begin{tabular}{|c|c|c|c|c|c|c|c|}
\hline \multirow[t]{2}{*}{ Parameter } & \multicolumn{2}{|c|}{ Mean \pm St. dev } & \multirow[b]{2}{*}{ CLWW } & \multirow[t]{2}{*}{ Parameter } & \multicolumn{2}{|c|}{ Mean \pm St. dev } & \multirow[b]{2}{*}{ CLWW } \\
\hline & WW & $\mathrm{FW}$ & & & WW & $\mathrm{FW}$ & \\
\hline $\mathrm{pH}$ & $7.8 \pm 0.30$ & $7.60 \pm 0.17$ & 8.00 & $\mathrm{Cl}\left(\mathrm{mg} \mathrm{L}^{-1}\right)$ & $93.20 \pm 23.69$ & $82.00 \pm 8.82$ & 350.00 \\
\hline $\mathrm{NO}_{3}-\mathrm{N}\left(\mathrm{mg} \mathrm{L}^{-1}\right)$ & $3.90 \pm 1.42$ & $3.40 \pm 0.23$ & 30.00 & $\mathrm{Fe}\left(\mathrm{mg} \mathrm{L}^{-1}\right)$ & $0.72 \pm 0.13$ & $0.10 \pm 0.02$ & 5.00 \\
\hline $\mathrm{NH}_{4}-\mathrm{N}\left(\mathrm{mg} \mathrm{L}^{-1}\right)$ & $4.10 \pm 2.07$ & $2.10 \pm 0.12$ & 10.00 & $\operatorname{Mn}\left(\mathrm{mg} \mathrm{L}^{-1}\right)$ & $0.06 \pm 0.01$ & nd & 0.20 \\
\hline $\mathrm{PO}_{4}\left(\mathrm{mg} \mathrm{L}^{-1}\right)$ & $8.60 \pm 1.39$ & $0.08 \pm 0.01$ & & $\mathrm{Zn}\left(\mathrm{mg} \mathrm{L}^{-1}\right)$ & $0.04 \pm 0.00$ & $0.10 \pm 0.01$ & 2.00 \\
\hline $\mathrm{K}\left(\mathrm{mg} \mathrm{L}^{-1}\right)$ & $22.40 \pm 6.01$ & $6.75 \pm 0.67$ & & $\mathrm{Cu}\left(\mathrm{mg} \mathrm{L}^{-1}\right)$ & $0.09 \pm 0.03$ & $0.01 \pm 0.00$ & 0.20 \\
\hline $\mathrm{Ca}\left(\mathrm{mg} \mathrm{L}^{-1}\right)$ & $99.03 \pm 31.20$ & $51.80 \pm 7.02$ & 400.00 & $\mathrm{~Pb}\left(\mathrm{mg} \mathrm{L}^{-1}\right)$ & $0.02 \pm 0.00$ & nd & 5.00 \\
\hline $\operatorname{Mg}\left(\mathrm{mg} \mathrm{L}^{-1}\right)$ & $84.19 \pm 17.92$ & $28.30 \pm 3.39$ & 60.00 & $\mathrm{Ni}\left(\mathrm{mg} \mathrm{L}^{-1}\right)$ & $0.01 \pm 0.00$ & $0.10 \pm 0.01$ & 0.20 \\
\hline $\mathrm{Na}\left(\mathrm{mg} \mathrm{L}^{-1}\right)$ & $275.25 \pm 55.22$ & $50.70 \pm 8.05$ & 207.00 & $\mathrm{Cd}\left(\mathrm{mg} \mathrm{L}^{-1}\right)$ & nd & nd & 0.01 \\
\hline
\end{tabular}

Table (2): Chemical and physical characteristics of the soil in the experiment site at beginning of the experiment.

\begin{tabular}{|c|c|c|c|}
\hline Soil properties & Mean & Soil properties & Mean \\
\hline Texture & SCL & $\mathrm{Na}\left(\mathrm{mg} \mathrm{kg}{ }^{-1}\right)$ & 2.10 \\
\hline $\mathrm{pH}$ & 8.10 & Fe $\left(\mathrm{mg} \mathrm{kg}^{-1}\right)$ & 4.90 \\
\hline $\operatorname{EC}\left(\mathrm{dS} \mathrm{m}^{-1}\right)$ & 1.40 & $\operatorname{Mn}\left(\mathrm{mg} \mathrm{kg}^{-1}\right)$ & 8.00 \\
\hline OM (\%) & 0.81 & $\mathrm{Zn}\left(\mathrm{mg} \mathrm{kg}{ }^{-1}\right)$ & 3.20 \\
\hline $\mathrm{N}(\%)$ & 0.22 & $\mathrm{Cu}\left(\mathrm{mg} \mathrm{kg} \mathrm{g}^{-1}\right)$ & 2.50 \\
\hline$P\left(m g \mathrm{~kg}^{-1}\right)$ & 224.00 & $\mathrm{~Pb}\left(\mathrm{mg} \mathrm{kg^{-1 }}\right)$ & 0.24 \\
\hline $\mathrm{K}\left(\mathrm{mg} \mathrm{kg} \mathrm{g}^{-1}\right)$ & 154.00 & $\mathrm{Ni}\left(\mathrm{mg} \mathrm{kg} \mathrm{g}^{-1}\right)$ & nd \\
\hline $\mathrm{Ca}\left(\mathrm{mg} \mathrm{kg} \mathrm{g}^{-1}\right)$ & 326.00 & $\mathrm{Cd}\left(\mathrm{mg} \mathrm{kg} \mathrm{g}^{-1}\right)$ & nd \\
\hline $\operatorname{Mg}\left(\mathrm{mg} \mathrm{kg}^{-1}\right)$ & 37.70 & & \\
\hline
\end{tabular}

SCL: Silty clay loamy soil; OM: Organic matter.

the recommended maximum limit (Ayers and Westcot, 1985). On the contrary, the levels of calcium $(\mathrm{Ca})$, cupper $(\mathrm{Cu})$, iron $(\mathrm{Fe})$, manganese ( $\mathrm{Mn})$, nickel $(\mathrm{Ni})$, lead $(\mathrm{Pb})$, and zinc $(\mathrm{Zn})$ were within the sufficiency range for plant growth. The level of cadmium $(\mathrm{Cd})$ was below the detection limit.

\subsection{Soil properties}

Some properties of the soil used in this study are given in Table (2). The soil texture is sandy clay loam. It is clear that the soil tend to have relatively high $\mathrm{pH}$ value (1:1). Soil analyses have shown that soil has low E.C. $\left(1.4 \mathrm{dS} \mathrm{m}^{-1}, 1: 1\right)$ and low organic matter content $(0.81 \%)$. The total soil-N was between $0.15 \%-0.22 \%$, while the available $\mathrm{P}$ was between $155-224 \mathrm{mg} \mathrm{kg}^{-1}$ which is considered optimal for most crops (Walsh and Beaton, 1973). Trace and micro elements concentrations were relatively low.

\subsection{Olive oil elemental compositions}

The main effects of wastewater irrigation on the elemental composition of olive oil are divided into three groups of elements: (1) trace elements $(\mathrm{Cd}, \mathrm{Co}$ and $\mathrm{Pb}$,) and salts $(\mathrm{Cl}$ and $\mathrm{Na}$ ); (2) micro nutrients ( $\mathrm{Fe}, \mathrm{Mn}$ and $\mathrm{Zn})$; and (3) macronutrients ( $\mathrm{Ca}, \mathrm{K}$ and $\mathrm{Mg}$ ).

\subsubsection{Trace elements}

The trace elements $(\mathrm{Cd}, \mathrm{Co}$ and $\mathrm{Pb})$ and salts $(\mathrm{Cl}$ and $\mathrm{Na})$ are not essential for plantnutrition in large amounts, and can have phytotoxic effects, even at low concentrations. Among heavy metals, Cd plays a major role; its presence is due to the growing use of sewage sledges and other wastes in agricultural lands. $\mathrm{Cd}$ is absorbed by plants and enters the food chain; and may cause severe problems to human health (Crosby, 1977). However, the concentration of $\mathrm{Cd}$ in oil was undetectable for both cultivars and irrigation treatments. The $\mathrm{Co}$ and $\mathrm{Pb}$ were undetectable in the olive oil of both cultivars. Increasing salinity of wastewater significantly increased olive oil $\mathrm{Cl}$ contents of 'Improved Nabali' and 'Nabali' oils (Fig. 1a). This result is highly confirmed by many authors (Al-Gazzaz, 1999; Bernstein et al., 2006; Al-Absi et al., 2008) wastewater increased $\mathrm{Cl}$ content in the aerial part of the olive tree. Results of $\mathrm{Cl}$ and $\mathrm{Na}$ accumulation in 'Nabali' oil support previous work (Tattini et al., 1992; Klein et al., 1994) describing ion exclusion and retention of $\mathrm{Cl}$ as well as $\mathrm{Na}$ in aerial part of the olive tree. 

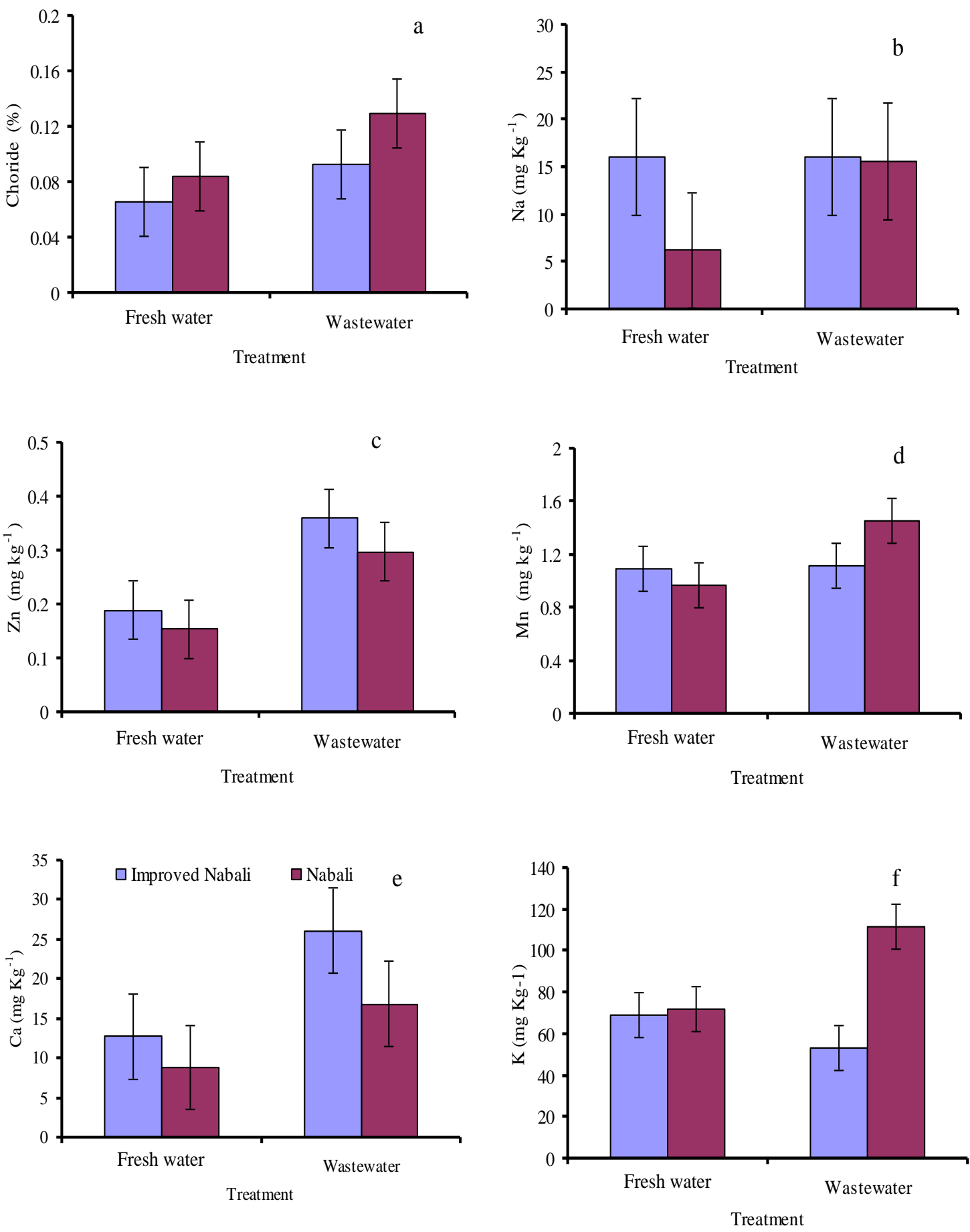

Fig. (1): Olive oil contents of chloride (a), sodium (b), zinc (c), manganese (d), calcium(e) and potassium (f) of 'Improved Nabali' and 'Nabali' olives as influenced by recycled effluent irrigation. 
The Na concentration of 'Nabali' olive oil increased using wastewater irrigation; however, 'Improved Nabali' shows no effect (Fig. 1b). Even though, the contents of leaf $\mathrm{Na}$ of the two cultivars were increased (Al-Absi et al., 2008). This can be explained to higher exclusion and translocation of $\mathrm{Na}$ to the upper parts of the olive tree in 'Nabali' for salt tolerance. Tolerance of olive tress to salt seems to be cultivar-dependent (Chartzoulakis, et al., 2004). At low and moderate salinities leval, most olive cultivars exhibit $\mathrm{Na}$ exclusion capacity (Tattini et al., 1992; Chartzoulakis et al., 2002). A relatively positive high correlations between the concentrations of the pairs of $\mathrm{Na}$ and $\mathrm{Ca}$ $(\mathrm{r}=0.77), \mathrm{Zn}(\mathrm{r}=0.43)$ were noticed.

\subsubsection{Micro nutrients}

Although essential for plant growth, micronutrients $(\mathrm{Fe}, \mathrm{Mn}$ and $\mathrm{Zn}$ ) can produce toxic effects if they reach very high concentration in the plant tissue.

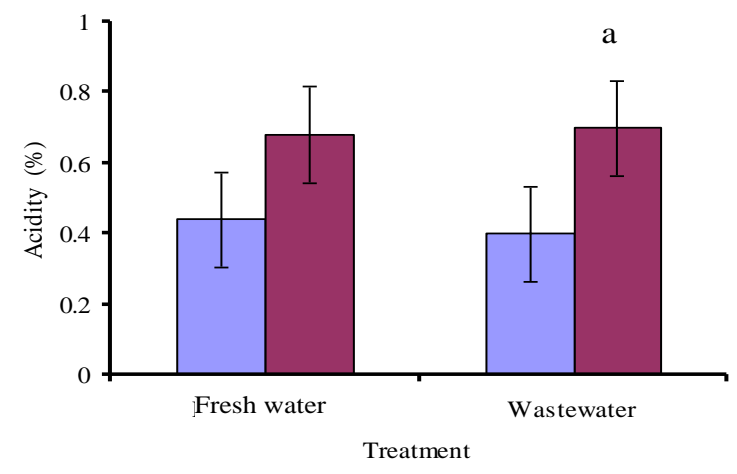

in the soil.

Despite the clear effect of increasing $\mathrm{Zn}$ accumulation induced by wastewater irrigation (Fig. 1c), olive oil content of $\mathrm{Zn}$ was relatively far from the maximum permissible concentration for oil $\left(10 \mathrm{mg} \mathrm{kg}^{-1}\right)$ (Angelova et al., 2004). There were a relatively positive correlations between the concentrations of the pairs of $\mathrm{Zn}$ and the other elemental $(\mathrm{Ca}(\mathrm{r}=0.68), \mathrm{Na}(\mathrm{r}=0.43))$.

\subsubsection{Macro nutrients}

Irrigation with treated wastewater relatively increased the oil content of $\mathrm{Ca}, \mathrm{K}$ and $\mathrm{Mg}$ (Figs.1e and f). A considerable difference was found in the elemental composition between the two cultivars. It is clear in Fig. (1e) that increasing salinity of wastewater increased the oil $\mathrm{Ca}$ content for both cultivars. There were a relatively positive high correlations between the concentrations of the pairs of $\mathrm{Ca}$ and $\mathrm{Na}$ $(\mathrm{r}=0.77), \mathrm{Zn}(\mathrm{r}=0.68)$.

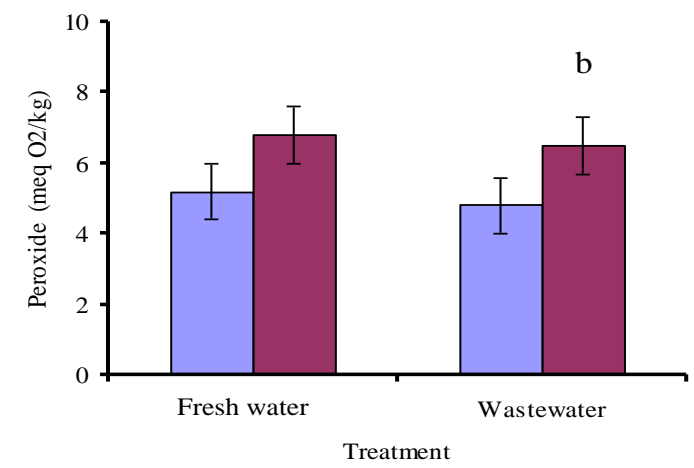

Fig. (2): Olive oil acidity percentages(a) and peroxide values (b) of 'Improved Nabali', and 'Nabali' olives as influenced by recycled effluent irrigation.

Concentrations of $\mathrm{Fe}$ in olive oil were undetectable and lower than the accepted maximum permissible concentrations for $\mathrm{Fe}$ $\left(0.1 \mathrm{mg} \mathrm{kg}^{-1}\right)$ (Angelova et al., 2004). The results showed that irrigation of 'Nabali' with treated wastewater significantly increased the oil content of Mn, while the oil Mn content of oil of 'Improved Nabali' remained constant (Fig.1d). Oil Mn contents of both cultivars under irrigation with both fresh and treated wastewater were within the range accepted for human health (WHO). The concentration of $\mathrm{Mn}$ in wastewater was relatively low and the accumulation of Mn found in olive oil for both cultivars and treatments, must be a reflection of an inherent high Mn availability
A considerable variation in the oil $\mathrm{K}$ content between the two tested cultivars irrigated with treated wastewater was observed. 'Nabali' had significantly higher K oil content than 'Improved Nabali' (Fig. 1f). The observed increase in $\mathrm{K}$ concentration at the current investigation, which resulted in a relatively similar $\mathrm{K} / \mathrm{Na}$ ratio, may provide a mechanism by which olive plant achieve ionic balance following uptake of $\mathrm{Na}$. The analysis indicated presence of a relatively positive weak correlation between oil $\mathrm{Na}$ and $\mathrm{K}$ concentrations. A relatively positive and negative weak correlation between the concentrations of the pairs of $\mathrm{K}$ and other oil elemental content of $\mathrm{Ca}, \mathrm{Na}, \mathrm{Zn}$, and $\mathrm{Mn}$. 
The $\mathrm{Mg}$ concentration was undetectable in oils of both cultivars and irrigation treatments.

\subsection{Oil quality}

Peroxide values and acidity percentages were not significantly affected by irrigation with treated wastewater (Fig.2a and b). The oxidation occurrence as a result of mechanical injuries to fruit accrued during harvest, which determintal to oil quality, leads to increased acidity and peroxide values (Servili et al., 1999). In our study, the fruit was picked carefully by hand so that no injuries were inflicted; peroxide and acidity were not changed due to irrigation with wastewater compared with fresh water (Fig.2). This makes sense since it is well known that these indices of are mostly affected by fruit handling and paste manipulation (Uceda and Hermoso, 1999) rather than source of irrigation.

\section{Conclusion}

Regarding olive oil elemental composition and quality, it seems that recycled effluent can be used for olive trees irrigation as the elemental concentrations were lower than the maximum permissible concentration and the oil quality indices were not changed using treated wastewater. Metallic cations: $\mathrm{Cd}, \mathrm{Co}$, $\mathrm{Fe}, \mathrm{Mg}, \mathrm{Pb}$ were below the detected limits and below the maximum permissible concentration. $\mathrm{Ca}, \mathrm{K} \mathrm{Mn}, \mathrm{Na}, \mathrm{Zn}$ were found in all oils. The concentrations of these elemental were relatively higher in the olive oils irrigated with treated wastewater but lower than the maximum permissible concentration. There were significant correlations between the concentrations of the some pairs of elemental. These results indicate that this kind of wastewater is suitable for application to olive orchards under irrigation for olive oil production purposes.

\section{Acknowledgement}

This study was supported by grant from the Deanship of Scientific Research., University of Mutah.

\section{REFERENCES}

Al-Absi K. M., Al-Nasir F. and Mahadeen A. (2008). Mineral composition of three olive cultivars irrigated with treated industrial wastewater. Agric. Water Manage. ( In press ).
Al-Gazzaz N.M. (1999). Long-term effect of Khirbet El-Samra treatment water irrigation on soil and olive quality, Jordan Univ., Faculty of Graduate Studies, Master Thesis.

Angelova V., Ivanova R., Delibaltova V. and Ivanov K. (2004). Bio-accumulation and distribution of heavy metals in fibre crops (flax, cotton and hemp). Indust. Crops and Prod. 19(3): 197-205.

Ayers R.S. and Westcot D.W. (1985). Water quality for agriculture. FAO Irrigation and Drainage Papers 29 (Rev. 1). FAO, Rome.

Bernstein N., Bartal A., Friedman H., Rot I., Snir P., Chazan A. and Ioffe M. (2006). Application of treated wastewater for cultivation of roses (Rosa hybrida) in soil-less culture. Sci. Hort. 108:185-193.

Chartzoulakis K., Loupassaki M., and Androulakis, I. (2002). Comparative study on $\mathrm{NaCl}$ salinity of six olive cultivars. Acta Hort. 586 (1), 497-502.

Chartzoulakis K., Psarras G., Vemmos S. and Loupassaki M. (2004). Effects of salinity and potassium supplement on photosynthesis, water relations and $\mathrm{Na}$, $\mathrm{Cl}, \mathrm{K}$ and carbohydrate concentration of two olive cultivars. Agric. Res. 27 (1):75-84.

Cheesman J.M. (1988). Mechanisms of salinity tolerance in plants. Plant Physiol. 87:547-550.

Correia F.N. (1999). Water resources in the Mediterranean region. Water Intern. 24 (1): 22-30.

Crosby N.T. (1977). Determination of metals in food: a review. The Analyst 102: 225-276.

Greenberg A.E., Trussell R.R., Clesceri L.S. and Franson M.A.H. (1985). Ed. Standard Methods for the Examination of Water and Wastewater, American Public Health Association, Washington, DC.

Hamdi A., Abu-Zeid M. and Lacirignola C. (1995). Water crisis in the Mediterranean: agricultural water demand management. Water Intern. 20 (4):176-187.

Klein I., Ben-Tal Y., Lavee S., De Malach J. and David I. (1994). Saline irrigation of cv Manzanilo and Uomo di Piccione 
trees. Acta Hort. 356:176-218.

Ministry of Agriculture (2005). Agricultural Statistics Department. Amman, Jordan.

Pereira L.S., Cordery I. and Iacovides I. (2002). Coping with Water Scarcity. UNESCO, Paris.

Servili M., Mariotti F., Baldioli M. and Montedoro G.F. (1999). Phenolic composition of olive fruit and VOO: distribution in the consecutive and evolution during the oil mechanical extraction process. Acta Hort. 474:609-619.

Shatanawi M., Al-Zu'bi Y. and Al-Jayoussi O. (2003). Irrigation Management Dynamics in the Jordan Valley, Kluwer Academic Publishers, Netherlands.

Siebe C. (1995). Heavy metal availability to plants and soils irrigated with wastewater from Mexico City. Water Sci. Tech. 32: 29-34.
Snedecor G.W. and Cochran W.G. (1980). Statistical Methods ( $7^{\text {th }}$ ed.), Iowa State University Press, Ames.

Tandon H.L.S. (1995).Micro nutrients in soils, crops and fertilizers. A Soundbook cum- Directory, Fertiliser Development and Consultation Organisation, New Dehli, India.

Tattini M., Bertoni P. and Caselli S. (1992). Genotypic responses of olive plants to sodium chloride. J. Plant Nutri. 15 (9): 1467-1485.

Uceda M. and Hermoso M. (1999). The quality of olive oil. In: D. Barranco, R. Fernández-Escobar and L. Rallo, Editors, The olive tree, Ediciones Mundi-Prensa, Madrid, 571-596.

Walsh M. and. Beaton J.D (1973). Soil Testing and Plant Analysis, Rev. Ed. Soil Sci. Soc. of Am., Madison.

$$
\begin{aligned}
& \text { تأثير الري بالمياه المعالجة علي نوعية الزيت لصنفيت الجافين من أصناف الزيتون } \\
& \text { خالد العبسي - أسامة مهاوش } \\
& \text { قسم الإنتاج النباتي ـ كلية الزر اعة ـ جامعة مؤنة ـ الكركـ الأردن }
\end{aligned}
$$

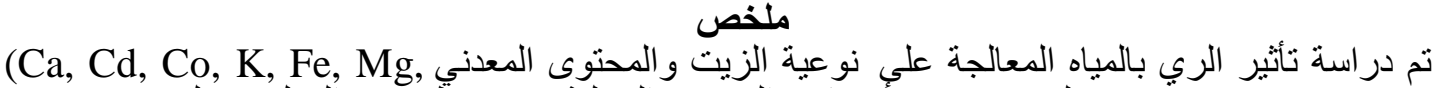

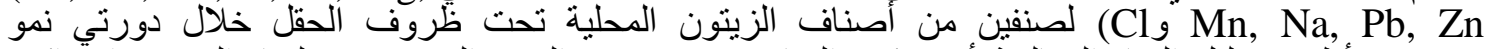

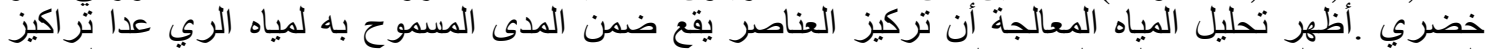

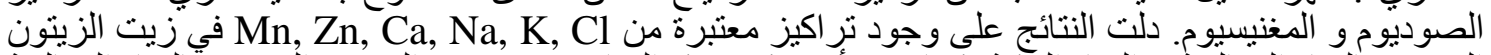

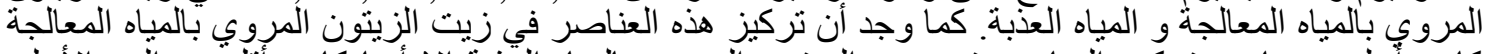

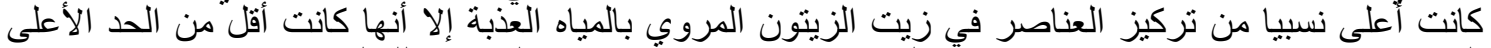

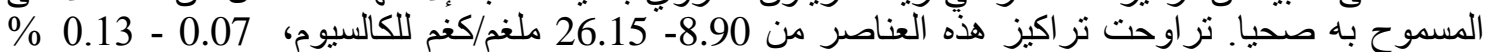

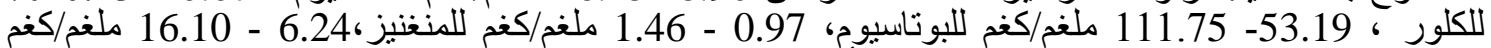

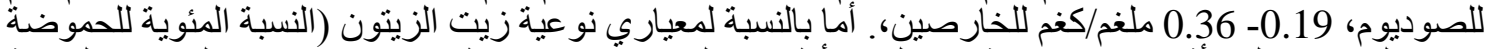

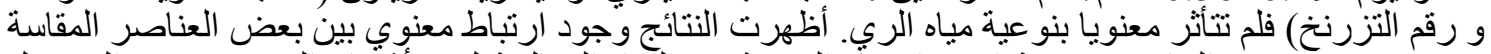
Ca-Na, Zn

على الزيت.

المجلة العلمية لكلية الزراعة - جامعة القاهرة - المجلد (60) العدد الثناني (أبريل 2009 ) :219-213. 